\title{
SEASONAL TROPICAL CYCLONE ACTIVITY AND ITS SIGNIFICANCE FOR DEVELOPMENTAL ACTIVITIES IN VANUATU
}

\author{
V. SAVERIMUTTU \& M.E. VARUA \\ School of Business, Western Sydney University, Australia.
}

\begin{abstract}
Developing island nations in the Pacific are highly dependent on tourism receipts to support and sustain growth in their economies. Vanuatu consists of an archipelago of 83 islands with a population of approximately 260,000 people. Vanuatu is classified as a least developed nation with a predominance of subsistence agriculture as well as a heavy dependence on the tourism sector as mainstays of the economy. In 2015, a category 5 cyclone struck Vanuatu causing severe destruction in four of its six provinces damaging both of its key industries, tourism and agriculture. Australia, as a key development partner and as a provider of the majority of its tourists has a direct interest in the sustainability and stability of the Vanuatu economy. Australia provides financial as well as humanitarian assistance to Vanuatu in the event of a crisis as well as for developmental purposes. Tropical cyclones are a normal phenomenon in the Southern hemisphere generally during the months of November to April. Even if a cyclone does not make landfall, strong gusts of wind and rainfall can cause significant damage through flooding. Although people can be trained in disaster management techniques and thereby achieve a reduction in the death toll, the damage to property and key industries are inevitable. This paper investigates the impact of cyclone activity on the economy of Vanuatu from the beginning of this century and its significance for the developmental challenges that face this nation. The paper also explores the dependence of Vanuatu on aid programmes and its implications for the management of extreme weather events in order to promote the sustainability of its key industries.

Keywords: aid, sustainable development, tourism, tropical cyclones and economic impact, vanuatu.
\end{abstract}

\section{INTRODUCTION}

Developing island nations in the Pacific are essentially agricultural in nature with poorly developed manufacturing sectors and limited natural resources. Nevertheless, with destination attributes such as pristine beaches, active volcanoes and cultural traditions, which have withstood the passage of time into modernity, these small island developing states (SIDS) are amply endowed for the promotion of tourism. Consequently, the only viable alternative to support and sustain growth in these economies is a high dependence on the tourism sector. Tourism in these nations is not only a key contributor to Gross Domestic product (GDP) and employment, but it is also a major foreign exchange earner and pays for much needed imports to support the development and sustainability of these economies. However, these SIDS are disproportionately vulnerable to natural disasters. The tourism sector, in particular, is susceptible due to its seasonal nature as well as the destruction of its tangible physical infrastructure and intangible destination image and reputation [1] as a result of exposure to natural hazards.

Fourteen of the 39 countries listed by the United Nations [2] as SIDS are located in the Pacific region. To emphasise the vulnerability of these islands to natural disasters, Pelling and 
Uitto [3] have documented the occurrences of hazardous events during the last century in ten of these islands. The details, including the effect of these disasters where information was available are given in Table 1 [3] below. Sufficient information was not available for the other four islands. These extreme events include cyclones, tsunamis, earthquakes, droughts and active volcanism.

During the latter part of the last century, in 1994, a volcano erupted in Papua New Guinea (PNG) and wiped out a major city. Vanuatu experiences active volcanism from time to time as well and the danger to the local communities is that acid rain and lava flow could destroy food crops. An earthquake followed by a tsunami with devastating effects, including loss of life, occurred in 1998 in PNG. Vanuatu also experienced earthquakes followed by smaller tsunamis in 1999 and 2002. According to Meheux et al. [4], during the years 1993 to 2005, excluding Kiribati, destructive cyclones and severe flooding occurred in all of the Pacific nations listed in Table 1 [3]. Tropical cyclones (TCs) are a normal phenomenon in the southern hemisphere generally occurring during the months of November to April. According to the World Bank [5], during the period 1950 to 2004, 76\% of the natural disasters reported in this area were caused by TC activity. Diamond et al. [6] found that during the period 19702010 there was an average of 12.9 storms per full season (November to April) and 4.1 developed into categories 3, 4 and 5 TCs. The average of occurrences of category 5 TCs was 0.5 per season based on a total of 20 TCs during this period. Even if a cyclone does not make landfall, strong gusts of wind and rainfall can cause significant damage through flooding and other hazards. Although people can be trained in disaster management techniques and thereby achieve a reduction in the death toll, the damage to property and key industries are inevitable.

In this disaster prone region, between the years 1970 and 2010, Vanuatu experienced the highest TC frequency of 3.9 in a full season [6]. Vanuatu is an archipelago of 83 islands with a population of approximately 260,000 people. The country is classified as a least developed nation with a predominance of subsistence agriculture as well as a heavy dependence on the tourism sector as mainstays of the economy [7]. In 2015, a category 5 cyclone struck Vanuatu causing severe destruction in four of its six provinces damaging both of its key industries, tourism and agriculture. Australia, as a key development partner and as a provider of the

Table 1: Hazardous events in the Pacific Islands during the period 1900 to 2000.

\begin{tabular}{lcccc}
\hline Country & $\begin{array}{c}\text { Events } \\
\text { 1900-1997 }\end{array}$ & $\begin{array}{c}\text { Events } \\
\text { 1987-1997 }\end{array}$ & Total Deaths & Total Affected \\
\hline Cook Islands & 9 & 4 & 45 & 900 \\
Fiji & 41 & 9 & 521 & 15,887 \\
Kiribati & 2 & 0 & 20 & no data \\
Niue & 4 & 1 & no data & no data \\
Papua New Guinea & 47 & 16 & 7797 & 728,940 \\
Samoa & 8 & 3 & 283 & no data \\
Solomon Islands & 26 & 5 & 403 & no data \\
Tonga & 55 & 4 & 14 & no data \\
Tuvalu & 5 & 2 & 6 & no data \\
Vanuatu & 32 & 11 & 174 & no data \\
\hline
\end{tabular}


majority of its tourists has a direct interest in the sustainability and stability of the Vanuatu economy. Australia provides both financial and humanitarian assistance to Vanuatu in the event of a crisis as well as for developmental purposes. New Zealand too has an interest in the stability of the region and also provides emergency and developmental assistance. In signing the Waiheke declaration along with other Pacific nations, a commitment was made to strengthen the tourism sector in all the Pacific islands [7]. The UN [2] has also continuously reiterated that SIDS must be treated as special cases for both environmental and developmental purposes. Managing the growth of the tourism sector, while protecting the environment and cultural integrity, was recognised as a priority area. In 2014, Vanuatu was spotlighted as on target to shed its LDCS by 2017 [8]. The impact of cyclone Pam on the economy in 2015 may have hindered this goal to some extent. One year on the economy is yet to fully recover from its devastation.

The next section will explore the phenomenon of TCs. Following this, the impact of cyclone activity in the key industries of the economy of Vanuatu, from the beginning of this century, will be investigated. Data on cyclone activity and from the tourism and agricultural sectors will be utilised for this purpose. The paper will also explore the dependence of Vanuatu on aid programmes. Finally the significance of the impact of extreme weather for the developmental challenges that are faced by this nation and its implications for the management of extreme weather events, in order to promote the sustainability of its key industries, will be discussed.

\section{TROPICAL CYCLONES}

In the southern hemisphere, when the sea surface temperature rises above $26.5^{\circ} \mathrm{C}$, thunderstorms develop into tropical cyclones that revolve clockwise. As the cyclone develops the centre or the eye of the cyclone can range from $10 \mathrm{~km}$ to over $100 \mathrm{~km}$. The strongest winds and heaviest rainfall are at the wall of the eye, a dense cloud that surrounds the eye. Within the eye or centre there will be light winds and skies are often clear. When the wind gusts around the centre exceed $90 \mathrm{~km} / \mathrm{hr}$ the storm will be categorised as a cyclone and these gusts could exceed $280 \mathrm{~km} / \mathrm{hr}$ increasing the severity of the cyclone. A cyclone will dissipate over cooler water or as it moves inland, but in the process it could follow an erratic path and cause much damage. It can also last for many days [9].

As destructive winds are accompanied by heavy rainfall, apart from the damage to buildings and crops, the cyclone increases the risk of drowning from flash flooding that can occur inland and along coastal areas. It can also cause landslides. When a TC makes landfall the highest risk is from storm surges. This occurs when a dome of water from the sea, approximately 60 to $80 \mathrm{~km}$ wide, rises to about 2 to $5 \mathrm{~km}$ higher than the sea level during normal tide and floods the areas around the coast. Storm surges and waves can cause severe erosion along the coast and low lying atolls are in danger of being wholly submerged, especially if a storm surge occurs at high tide. Turbulence at sea could also damage moored vessels as well as those out in the ocean. Cyclones are categorised according to their severity and the Australian scale (Table 2: [10]) differs from that used in the United States. Even when a cyclone does not make landfall, those feeling the wind from the outer part of a category 4 or 5 cyclone often assume they have experienced a severe cyclone [9].

Diamond et al. [6] estimated that $27.9 \%$ of a total of 283 storms that occurred in the southwest Pacific area, during the years 1970 to 1990, developed into major TCs. From 1991 to 2010 the number of storms fell to 234 and $36.7 \%$ of these storms developed into severe TCs. The increase in proportion in the latter half of the period was found to be statistically significant. In addition, nearly $85 \%$ of the 21 category 5 TCs that occurred during the whole period, 
Table 2: Tropical cyclone categories in Australia.

\begin{tabular}{|c|c|c|c|c|}
\hline Name & Category & $\begin{array}{l}\text { Strength of } \\
\text { Gust }(\mathrm{km} / \mathrm{h})\end{array}$ & Effects & Extent of Damage \\
\hline $\begin{array}{l}\text { Tropical } \\
\text { Low }\end{array}$ & $\begin{array}{l}\text { Tropical } \\
\text { Depression }\end{array}$ & $>63$ & Gales & Minimal damage: crops, houses. \\
\hline $\mathrm{TC}$ & 1 & $90-125$ & Damaging winds & $\begin{array}{l}\text { Minimal damage: crops, trees, } \\
\text { houses. Boats may drag. }\end{array}$ \\
\hline $\mathrm{TC}$ & 2 & $125-164$ & $\begin{array}{l}\text { Destructive } \\
\text { winds }\end{array}$ & $\begin{array}{l}\text { Minor damage: houses. Signifi- } \\
\text { cant damage: signs, trees. Heavy } \\
\text { damage: crops. Power failure. } \\
\text { Boats may drift. }\end{array}$ \\
\hline $\begin{array}{l}\text { Severe } \\
\text { TC }\end{array}$ & 3 & $165-224$ & $\begin{array}{l}\text { Very destructive } \\
\text { winds }\end{array}$ & $\begin{array}{l}\text { Some roof and structural dam- } \\
\text { age. Power failure likely }\end{array}$ \\
\hline $\begin{array}{l}\text { Severe } \\
\mathrm{TC}\end{array}$ & 4 & $225-279$ & $\begin{array}{l}\text { Very destructive } \\
\text { winds }\end{array}$ & $\begin{array}{l}\text { Significant roof and structural } \\
\text { damage. Dangerous airborne de- } \\
\text { bris. Widespread power failures. }\end{array}$ \\
\hline Severe TC & 5 & $>280$ & $\begin{array}{l}\text { Extremely de- } \\
\text { structive Winds }\end{array}$ & $\begin{array}{l}\text { Extremely dangerous with wide- } \\
\text { spread destruction }\end{array}$ \\
\hline
\end{tabular}

occurred between 1991 and 2010. Their analysis confirmed that most occurrences of TCs were around Vanuatu, Fiji and New Caledonia. This is not surprising as Vanuatu is located in the Pacific Ring of Fire and at the centre of the cyclone belt [11]. Diamond et al. [12] reported that in the southwest Pacific region the TC season is at its height from January to March.

\section{IMPACT OF CYCLONE ACTIVITY ON KEY SECTORS IN VANUATU}

In order to examine the impact of cyclones on the tourism sector in Vanuatu, quarterly data, on cyclone activity [13] and tourist arrivals (by air) [14]) for the period 2001 to 2015, was utilised. Simple linear regression analysis reported in Table 3 confirmed the expected result, that cyclones during this period had a significantly negative impact on tourist arrivals and its growth rate, in the quarter that the event occurred $(\mathrm{Qc})$. The data showed that most of the cyclone activity took place during the months, January to March (Q1). The cyclone activity also had a significantly negative impact on arrivals in the next quarter $(\mathrm{Qn})$ but a positive result could not be confirmed for Qn+1. The growth rate in arrivals in Qn was positive but not significant. However, the growth rate in $(\mathrm{Qn}+1)$ with reference to the growth rate in Qn was positive and significant. These results imply that cyclones had affected tourist arrivals not only just in the quarter that it had occurred but also in the next two quarters.

One could argue that the results reported (Table 3) reflect seasonality rather than the impact of cyclones on the tourism sector. Information is widely available on tourism sites about the prevalence of cyclone activity during the months, January to March in Vanuatu. Thus, tourist arrivals by air are generally lower in Q1 than in other months. The general pattern of tourist arrivals (by air) can be seen in Table 4 [14] below. To reconfirm the impact of cyclones in Vanuatu from 2001 to 2015 further analysis was conducted. Since cyclones affect the agricultural sector as well, agricultural value added was used as a proxy for cyclones and its 
Table 3: Impact of cyclones on tourist arrivals 2001 to 2015.

\begin{tabular}{lll}
\hline & Cyclone $(\mathrm{Qc})$ & \\
\hline Variable & $\begin{array}{l}\text { Correlation } \\
\text { coefficient }\end{array}$ & P-value \\
\hline Arrivals: Qc & -0.38958 & $0.002999 * * *$ \\
Growth rate of arrivals: Qp to Qc & -0.43865 & $0.000808^{* * *}$ \\
Arrivals: Qn & -0.22471 & $0.099072^{*}$ \\
Growth rate of arrivals: Qc to Qn & 0.215964 & 0.116777 \\
Arrivals: Qn+1 & 0.18178 & 0.18833 \\
Growth rate of arrivals: Qn to Qn+1 & 0.505436 & $0.000113 * * *$ \\
\hline
\end{tabular}

$* * * * * * *$ significant at $1 \%, 5 \%$ and $10 \%$ respectively

Qc: Current quarter; Qp: Previous quarter; Qn: Next quarter

Table 4: Seasonality in tourism arrivals (by air) in Vanuatu.

\begin{tabular}{cccccc}
\hline Year & Quarter 1 (Q1) & Quarter 2 (Q2) & Quarter 3 (Q3) & Quarter 4 (Q4) & Total \\
\hline 2011 & 16,600 & 22,181 & 29,897 & 25,282 & 93,960 \\
2012 & 19,798 & 25,310 & 34,357 & 28,696 & 108,161 \\
2013 & 19,520 & 27,538 & 34,248 & 28,803 & 110,109 \\
2014 & 19,832 & 25,533 & 34,599 & 28,844 & 108,808 \\
2015 & 18,750 & 18,654 & 27,592 & 24,956 & 89,952 \\
\hline
\end{tabular}

Table 5: Impact of cyclones on the tourism and agricultural sectors 2001 to 2015.

\begin{tabular}{llcl}
\hline Variable & Proxy for Cyclone & $\begin{array}{l}\text { Correlation } \\
\text { coefficient }\end{array}$ & P-value \\
\hline Tourist Arrivals & $\begin{array}{l}\text { Agriculture value } \\
\text { added }\end{array}$ & 0.945426 & $0.0000^{* * *}$ \\
Tourism Receipts & $\begin{array}{l}\text { Agriculture value } \\
\text { added }\end{array}$ & 0.958122 & $0.0000^{* * *}$ \\
\hline
\end{tabular}

***,*** significant at $1 \%, 5 \%$ and $10 \%$ respectively.

impact was independently tested on tourist arrivals and tourism receipts. In this case, the expected sign is positive as cyclones affect both the tourism and agriculture sectors negatively. As quarterly data were not available, annual data were obtained for the years 1995 to 2013 for these variables [15]. As shown in Table 5 the signs are positive and significant confirming that both sectors were affected by cyclones during the period under review. 
Table 6: Tourism arrivals (by sea) in Vanuatu.

\begin{tabular}{lccccc}
\hline Year & Quarter 1 (Q1) & Quarter 2 (Q2) & Quarter 3 (Q3) & Quarter 4 (Q4) & Total \\
\hline 2011 & 40,965 & 51,119 & 31,988 & 30,866 & 154,938 \\
2012 & 63,601 & 45,833 & 43,280 & 60,529 & 213,243 \\
2013 & 65,678 & 59,842 & 45,771 & 69,192 & 240,483 \\
2014 & 67,627 & 55,660 & 40,144 & 56,744 & 220,175 \\
2015 & 52,256 & 29,171 & 48,954 & 67,090 & 197,471 \\
\hline
\end{tabular}

Visitors on cruise ships are excluded from the previous analyses. These are day visitors to Vanuatu and are generally unaffected by cyclone activity in that their travel is booked and paid for well ahead of time and accommodation and other services are on board the cruise ships. However, it appears that cyclone Pam has had an impact as the number of passengers in the quarter following this cyclone fell to 29,171 , the lowest number of day visitors in any quarter during the years 2011 to 2015 (Table 6 [14]).

\section{EMERGENCY AND DEVELOPMENTAL AID}

In the wake of the category 5 Cyclone Pam, which struck Vanuatu in March of 2015, the Australian Government provided $\$ 10$ million dollars for immediate humanitarian support. \$5 million of this was for the purpose of search and rescue, medical teams and other humanitarian relief items including transport and logistics provided by Australian personnel and $\$ 5$ million was provided through United Nations agencies and other non-governmental organisations for the same purpose. A further $\$ 5$ million was provided for early recovery and $\$ 35$ million was set aside for long term recovery taking Australia's total package of emergency assistance to $\$ 50$ million [16]. This commitment was in addition to the official development assistance provided by Australia to Vanuatu, as its largest development partner.

Immediate assistance was required for clean water, food, shelter, health care and psychosocial care requiring quick access to financing [17]. The long term damage to the nation was determined to be around AU\$600 million, which is approximately 64\% of Vanuatu's GDP and the total recovery costs were estimated to be AU\$426 million [16]. Vanuatu was not the only country affected by Cyclone Pam. Others in the south Pacific included Tuvalu, the Solomon Islands and Kiribati. Given the extent of the total damage, the international community responded immediately with emergency assistance for all four countries, with Vanuatu receiving the largest share [18].

Vanuatu is not only categorised as SIDS but also has least developed country status (LDCS) and at the time the cyclone struck the country was in transition to graduate from its LDCS by December 2017 [8]. In October 2015, the Prime Minister of Vanuatu appealed to the United Nations to delay the country's graduation from LDCS as the cyclone had wiped out nearly 10 years of economic growth [19]. Countries are classified with LDCS based on low income, human assets weakness and economic structural vulnerability to exogenous shocks and are entitled to preferential treatment in international trade, official development assistance, technical cooperation and other forms of assistance. The current list with LDCS includes 48 countries [20].

Samoa in the same region suffered a tsunami in 2009 and a category 4 cyclone (Evan) in 2012 and graduated from LDCS in January of 2014. Although Cyclone Pam had a devastating 
Table 7: Response of international aid to cyclone activity in Vanuatu 1981-2012.

\begin{tabular}{llll}
\hline Variable & Proxy for Cyclone & $\begin{array}{l}\text { Correlation } \\
\text { coefficient }\end{array}$ & P-value \\
\hline $\begin{array}{l}\text { Growth rate of Over- } \\
\text { seas aid in } t+1\end{array}$ & $\begin{array}{l}\text { Growth rate of agri- } \\
\text { cultural value added in } \\
\text { time t (AGVACT\$) }\end{array}$ & -0.04791 & $0.079458^{*}$ \\
\hline
\end{tabular}

$* * *, * * *$ significant at $1 \%, 5 \%$ and $10 \%$ respectively

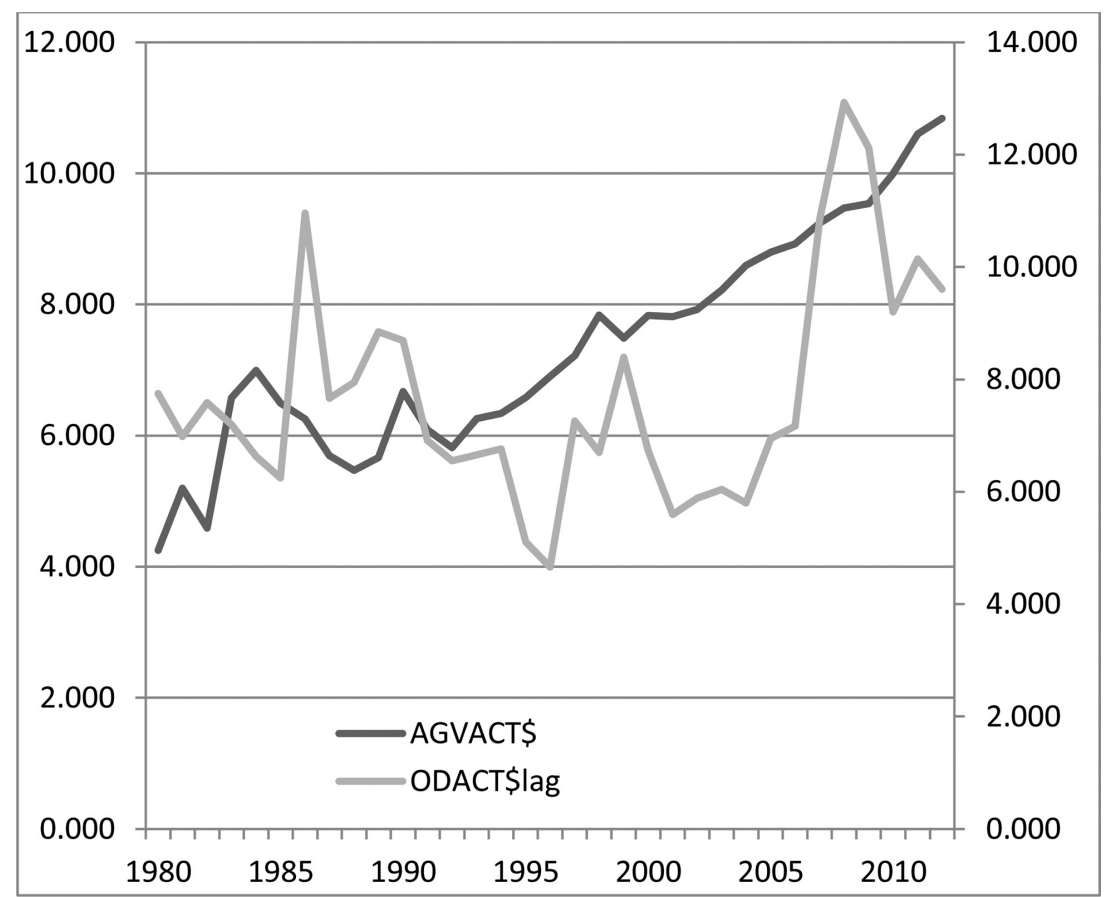

Figure 1: International aid and cyclone activity in Vanuatu 1981-2012.

impact in Vanuatu, and the severity of the cyclones has been reported to be increasing since the 1990s, cyclone activity is not a new phenomenon for this country [6]. In addition, as reported previously Vanuatu is also vulnerable to other natural hazards such as tsunamis and volcanism and the Ni-Vanuatu have survived these for centuries [21]. Further, just prior to the cyclone the country was working with UNCTAD to shed its LDCS, despite cyclone and other hazards which were just as devastating in the past. This would imply that measures were in place to reduce the economic vulnerability to exogenous shocks. A question that has been raised is whether aid creates a moral hazard against risk reduction. For the governments of the Pacific nations, if the international community responds generously whenever disaster strikes, inaction in reducing risks appears rational. For donors, there is instant recognition and praise via social media and television networks for generosity, which is independent of any risk reduction efforts of the country [5]. Does emergency aid create dependence in these 
disaster prone nations? Simple linear regression analysis for the period 1981 to 2012 confirmed that the intensity of cyclone activity in a particular year was matched to some extent by increases in aid in the following year. The result (Table 7 [15]) was significant, but at 10\%, which is expected as cyclone activity is just one factor that has an impact on the amount of aid received. In the analysis, the growth rate of agricultural value added was used as a proxy to indicate the intensity of cyclones in time $t$ and the growth rate of aid was used as the dependent variable in time $t+1$. Figure 1 illustrates international aid and cyclone activity in Vanuatu from 1981 to 2012.

\section{MANAGING EXTREME WEATHER EVENTS AND CONCLUSIONS}

An extreme weather event is referred to as a disaster when the affected community cannot cope with the impact. A study of the Banks Islands group in the Torba province of Vanuatu, by Campbell [21], revealed that the inhabitants of Mota Lava Island had their own procedures to cope with extreme weather events. Traditionally, to maintain food security, a diversity of crops, including resilient crops like yams and famine foods like sago, were cultivated to reduce the possibility that all the crops in any location would be destroyed. Surplus cultivation was stored or preserved for the aftermath of a cyclone. A communal relationship was maintained among the islands and surpluses were exchanged for shell money from those who were affected. Structural damage to islands resulted in people relocating to unaffected areas and most communities lived on higher land away from the coast line. After colonial contact traditional practices changed. Agricultural diversity was replaced with mono-cultural cash cropping. The exchange of surpluses for shell money was no longer a regular occurrence. Following the cyclone in 1873 , the response was mostly traditional but due to changes in traditional practices and perhaps loss of knowledge the response to the cyclone was not very effective. The critical conditions that resulted led to food relief being provided for the first time in the Banks Islands which may have led to expectations of relief in the event of future disasters.

Apart from the questions that have been raised as to whether aid has created a dependency, it may also have increased the vulnerability of communities in Vanuatu and other Pacific Islands, contributing to a loss of indigenous knowledge. Indigenous communities have survived natural disasters for centuries with risk reduction and mitigation mechanisms conveyed orally through the generations. Thus, this knowledge permeates their culture and traditions and is specific to their location. Coping strategies introduced into these societies, following the granting of aid, may have inadvertently deterred traditional responses. However, some of the modern challenges may also be outside the capacities of these communities to manage [22].

While responses of the international community in a disaster are highly acclaimed and very visible, the benefits of risk reduction and mitigation methods or systems in place are rarely evident [5]. After Cyclone Pam, the low death toll in Vanuatu was attributed to emergency preparation plans being in place in many communities and essential information being transmitted across the island via social media, the radio and approximately 6 million SMS messages to 160,000 mobile phone users [23]. This certainly justifies the aid expended in setting up the National Warning Centre. When a disaster strikes and communities are vulnerable for whatever reason, the international community cannot ignore the need for emergency aid to address immediate humanitarian needs such as search and rescue, shelter, food and water, sanitation and health requirements. Nonetheless, the funds committed to long-term recovery and official development aid is an opportunity to establish good practices that will reduce the vulnerability of the communities that are likely to be affected when the next disaster strikes. 
Indigenous knowledge includes strategies for both adaptation and mitigation. However, for risk reduction, such knowledge has not been augmented by more recent forms of knowledge based on science and technology. Cooperation in this area, combining indigenous knowledge with more recent forms of knowledge in developing a framework for risk reduction, would not only value add to scientific climate data, to provide solutions that are appropriate for the location, but also address the gaps in indigenous knowledge and insufficiencies arising from new forms of social and environmental circumstances [24].

It is important to build confidence in the community by raising awareness of preventive planning that is being instituted in risk management strategies. When a cyclone occurs, apart from the impact on lives and food security, there can also be damage caused to infrastructure which will affect livelihoods in both the agriculture and tourism sectors. Reverting to the tradition of producing surpluses, to address food security in the aftermath of a cyclone, would require effective means of storage. Communities that have not been affected by the cyclone could transfer their surpluses to the Government for transport to the affected areas, instead of these communities waiting for food relief from abroad. Rural communities, that have abandoned cultivating sago due to the time consuming process to extract and prepare it, should be encouraged to cultivate this famine food. Agricultural diversity should also be encouraged to increase the range of staples and minimise the loss of livelihoods, as resilient food crops are likely to survive a cyclone. Advances in communication technology and modes of disseminating information have already proven to be a successful in minimising the death toll in Vanuatu. In designing infrastructure, the Cook Islands pilot project demonstrated that it is far cheaper to include risk management practices at the design stage rather than to repair it after it has been damaged by a disaster [5]. All these strategies help to build social capital and reduce the dependency on international aid, which can then be used to strengthen the institutions that assist in building social capital and for other sustainable developmental purposes.

In conclusion, tropical cyclones have affected communities in Vanuatu for centuries. In the past indigenous communities used traditional methods of coping with disaster and survived. Some of this knowledge, transmitted orally through the centuries and not documented, has been lost or is no longer practised and as such has increased the vulnerability of the people. A growing dependence on aid has also occurred. In recent years severe cyclone activity has increased in frequency. Depending on the severity of the cyclone and the ensuing wind, rainfall, flash flooding and storm surges the immediate impact on the affected communities have sometimes been devastating. An analysis of cyclone activity from the beginning of this century has revealed that key sectors of the Vanuatu economy, tourism and agriculture, have been significantly affected by cyclone activity during the period 2001 to 2015. This not only retards the growth of the economy but also increases the vulnerability of the Ni-Vanuatu and their need for assistance from the international community. There is a growing consensus for a partnership between indigenous traditional adaptive systems and modern adaptive systems to reduce risks. International aid can be put to effective use to reduce the vulnerability of the population by increasing social capital.

\section{REFERENCES}

[1] Meheux, K. \& Parker, E., Tourist sector perceptions of natural hazards in Vanuatu and the implications for a small Island developing state. Tourism Management, 27, pp. 69$85,2006$.

http://dx.doi.org/10.1016/j.tourman.2004.07.009 
[2] United Nations, International year of Small Island developing states 2014, Available at: http://www.un.org/en/events/islands2014/smallislands.shtml, Accessed 26 April 2016.

[3] Pelling, M. \& Uitto, J.I., Small Island developing states: natural disaster vulnerability and global change. Environmental Hazards, 3, pp. 49-62, 2001.

http://dx.doi.org/10.3763/ehaz.2001.0306

[4] Meheux, K., Dominey-Howes, D. \& Lloyd, K., Natural hazard impacts in small island developing states: a review of current knowledge and future research needs. Natural Hazards, 40, pp. 429-446, 2007.

http://dx.doi.org/10.1007/s11069-006-9001-5

[5] World Bank, Not if but when, Adapting to natural hazards in the Pacific Islands region: a policy note, 2006, Available at: http://documents.worldbank.org/curated/ en/2006/01/6589273/not-adapting-natural-hazards-pacific-islands-region-policy-note. Accessed 26 April 2016.

[6] Diamond, H.J., Lorrey, A.M. \& Renwick, J.A., A Southwest Pacific tropical cyclone climatology and linkages to the El Nino-Southern oscillation. Journal of Climate, 26, pp. 3-25, 2013.

http://dx.doi.org/10.1175/JCLI-D-12-00077.1

[7] Saverimuttu, V. \& Varua, M.E., Promoting sustainable tourism in the Pacific Forum Island countries. Proceeding of the 6th International Conference On Sustainable Tourism, eds. C.A. Brebbia, S. Favro \& F.D. Pineda, WIT Press: Southampton, pp. 27-38, 2014.

http://dx.doi.org/10.2495/st140031

[8] UNCTAD, Vanuatu prepares to shed 'least developed country' status with UNCTADled review of 'green' export opportunities, 2014, Available at: http://unctad.org/en/pages/newsdetails.aspx? OriginalVersionID=818 Accessed 25th April 2016.

[9] Bureau of Meteorology Australia, About tropical cyclones, Available at: http://www. bom.gov.au/cyclone/about/, Accessed 25th April 2016.

[10] Bureau of Meteorology Australia, Tropical cyclone intensity impacts, Available at: http://www.bom.gov.au/cyclone/about/intensity.shtml, Accessed 25 April 2016.

[11] GFDRR, Stories of impact. Supporting resilient recovery in Vanuatu after cyclone Pam, Available at: https://www.gfdrr.org/stories-impact-supporting-resilient-recovery-vanuatu-after-cyclone-pam, Accessed 27 April 2016.

[12] Diamond, H.J., Lorrey, A.M., Knapp, K.R. \& Levinson, D.H., Development of an enhanced tropical cyclone tracks database for the southwest Pacific from 1840 to 2010. International Journal of Climatology, 2011, Available at: http://digitalcommons.unl. edu/cgi/viewcontent.cgi?article=1256\&context=usdeptcommercepub, Accessed 27 April 2016.

[13] Australian Severe Weather, http://www.australiasevereweather.com/cyclones/summary_jtwc.htm, Accessed 25 April 2016.

[14] Vanuatu National Statistics Office, Various statistical bulletins, www.vnso.gov.vu/ Accessed 25 April 2016.

[15] World Bank, Vanuatu databank, http://data.worldbank.org/country/vanuatu, Accessed 7th April 2016.

[16] DFAT Australia, Australia support to Vanuatu following tropical cyclone Pam - fact sheet 2015, Available at: http://dfat.gov.au/about-us/publications/Documents/australiansupport-to-vanuatu-following-tropical-cyclone-pam-fact-sheet.pdf, Accessed 26 April 2016. 
[17] UNICEF, Cyclone Pam: one year on, Available at: http://reliefweb.int/report/vanuatu/ unicef-fast-facts-cyclone-pam-one-year-march-2016, Accessed 26 April 2016.

[18] USAID, South Pacific - tropical cyclone Pam, fact sheet \#3, 2015, Available at: https:// www.usaid.gov/crisis/tropical-cyclone-pam, Accessed 26 April 2016.

[19] Vanuatu Daily Post, LDC graduation delay, Available at: http://dailypost.vu/news/ldcgraduation-delay/article_46f50743-e141-5838-a039-61a840acb473.html, Accessed 28 April 2016.

[20] Alonso, J.A., Cortez, A.L. \& Klasen, S., LDC and other country groupings: How useful are current approaches to classify countries in a more heterogeneous developing world? 2014, Available at: http://www.un.org/en/development/desa/policy/cdp/cdp_background_papers/bp2014_21.pdf, Accessed 29 April 2016.

[21] Campbell, J.R., Disasters and development in historical context: Tropical cyclone response in the Banks Islands, northern Vanuatu, Available at: http://www.pacificdisaster.net/pdnadmin/data/original/JB_DM194_1990_VUT_TC_Disaster_Development_ Context.pdf, Accessed 25 April 2016.

[22] Kelman, I., Mercer, J. \& Gaillard, J.C., Indigenous knowledge and disaster risk reduction. Geography, 97(1), pp. 12-21, 2012.

[23] World Bank, Vanuatu, six months after cyclone Pam, Available at: http://www. worldbank.org/en/news/feature/2015/09/29/vanuatu-six-months-after-cyclone-pam, Accessed 3 May 2016.

[24] McNamara, K.E. \& Prasad, S.S., Coping with extreme weather: communities in Fiji and Vanuatu share their experiences and knowledge. Climatic Change, 123, pp. 121132, 2014.

http://dx.doi.org/10.1007/s10584-013-1047-2 